\title{
The role of cultural psychological orientations for flexibility in coping with stress in Polish adolescents
}

\author{
Znaczenie kulturowych orientacji psychologicznych dla elastyczności \\ w radzeniu sobie ze stresem polskiej młodzieży
}

Department of Psychology, Kazimierz Wielki University, Bydgoszzz, Poland

Correspondence: Agnieszka Kruczek, Department of Clinical Psychology, Department of Psychology, Kazimierz Wielki University, Leopolda Staffa 1, 85-867 Bydgoszzz, Poland, e-mail: agnesview@gmail.com

\begin{abstract}
Aim: The aim of the study was to assess the dominant cultural psychological orientation among Polish youth, the role of individualism and collectivism for flexibility in coping, and the assessment of the modifying role of gender and age of the studied youth for the relationship between the included cultural psychological orientations and the flexibility in coping with stress. Materials and methods: A total of 367 adolescents (131 boys and 236 girls) aged between 13 and 20 participated in the study. The following methods were used: the Individualism-Collectivist Questionnaire by Harry Triandis and Michele Gelfand, Flexibility in Coping with Stress Questionnaire by Basińska et al., and a personal survey. Results: Polish adolescents obtained the highest average score in the psychological orientation of vertical collectivism. There were statistically significant positive correlations between horizontal individualism, horizontal collectivism, vertical collectivism and flexibility in coping and its dimensions. Moreover, Polish adolescents' psychological orientation - horizontal individualism - was a predictor of flexibility in coping with stress and its dimensions. The analysis revealed that the model for the relationship between horizontal individualism and coping competences with the modifying role of age was statistically significant. Younger adolescents (from 13 to 17 years of age) were more individually oriented horizontally, and had higher coping competences, whereas in the group of older adolescents (>17.4) this effect was not observed. Conclusions: The results of the study are an important contribution to the recognition of flexibility in coping, but also answer numerous questions about its relationships with cultural psychological orientation.
\end{abstract}

Keywords: individualism, collectivism, flexibility in coping, adolescents

Streszczenie Wstęp: Celem przeprowadzonych badań była ocena dominującej kulturowej orientacji psychologicznej polskiej młodzieży, wpływu indywidualizmu i kolektywizmu na elastyczność w radzeniu sobie ze stresem oraz ocena modyfikującego znaczenia płci i wieku badanej młodzieży dla związku między kulturowymi orientacjami psychologicznymi i elastycznością w radzeniu sobie ze stresem. Materiał i metody: W badaniu wzięło udział 367 nastolatków (131 chłopców i 236 dziewcząt) w wieku 13-20 lat. W badaniach wykorzystano Skalę Orientacji Kulturowej Triandisa i Gelfand, Kwestionariusz Elastyczności w Radzeniu Sobie ze Stresem Basińskiej i wsp. oraz ankietę własną. Wyniki: Polscy nastolatkowie uzyskali najwyższy średni wynik w zakresie psychologicznej orientacji kolektywizmu wertykalnego. Występowały statystycznie istotne pozytywne korelacje między horyzontalnym indywidualizmem, horyzontalnym kolektywizmem, wertykalnym kolektywizmem a elastycznością w radzeniu sobie ze stresem i jej wymiarami. Ponadto orientacja psychologiczna indywidualizm horyzontalny była predyktorem elastyczności w radzeniu sobie ze stresem i jej wymiarów. Analiza wykazała, że model zależności między horyzontalnym indywidualizmem a kompetencjami radzenia sobie z modyfikującą rolą wieku był statystycznie istotny. Młodsze nastolatki (13-17 lat) były bardziej indywidualnie zorientowane wertykalnie, miały wyższe kompetencje radzenia sobie, podczas gdy w grupie starszych nastolatków ( $>17,4$ roku) efekt ten nie wystąpił. Wnioski: Prezentowane wyniki badań stanowią ważny wkład w rozumienie elastyczności w radzeniu sobie, ale także odpowiadają na liczne pytania dotyczące jej związków z kulturową orientacją psychologiczną.

Słowa kluczowe: indywidualizm, kolektywizm, elastyczność w radzeniu sobie, młodzież 


\section{INTRODUCTION}

$\mathrm{O}$ ver the last 25 years, the concepts of individualism and collectivism have been widely reviewed and verified. In particular, the focus was laid on cultures oriented towards individualism and collectivism, and their description. These explorations fit in well with the trend of intercultural research, which was relatively "narrow," and concentrated mainly on comparative studies of social groups from Eastern and Western cultures (Fijneman et al., 1996; Oyserman, 2017; Urban, 2008). However, many questions remain to be answered, in particular concerning such issues as various types of collectivism (i.e. familism, companionship, patriotism) (Matsumoto et al., 1996); the intensity of individualist/collectivist orientation depending on the situation in which individuals currently find themselves (Allik and Realo, 2004; Realo et al., 1997); behavioural variations in individuals manifesting individualist or collectivist orientations, including their coping with stress (Keller and Lamm, 2005; Tulviste and Mizera, 2010).

Research conducted in the post-communist countries has demonstrated an explicit change in cultural psychological orientations of individuals and the coexistence of collectivism and individualism at the family level (Tamis-LeMonda et al., 2007). Still, the individuals living in them were characterised by the collectivist orientation (Silbereisen, 2005), which was related to the parents who promoted socialisation goals that regarded interdependence (Keller and Lamm, 2005; Tulviste and Mizera, 2010). However, in the cultures of social transformation, an increase in individualism and the evaluation of autonomy as a socialisation goal was also observed (Kagitcibasi and Ataca, 2005; Tulviste and Mizera, 2010).

In recent years in Poland, there have been changes evidencing social transformations that move towards individualism and higher evaluation of autonomy. An increasing number of individually oriented persons does not mean, however, that the collectivist orientation has been completely abandoned (Cybal-Michalska, 2006; Urban, 2008), as principles typical of individualism and collectivism are deeply rooted in social structures and available in everyday situations (Oyserman, 2017).

\section{INDIVIDUALISM AND COLLECTIVISM}

The constructs of individualism and collectivism are of a polythetic nature (Triandis, 1995). They have already been discussed in the literature from a variety of angles and perspectives (Kim et al., 1994; Triandis, 1995): values (Hofstede, 1980), social systems (Parsons and Shils, 1951), cognitive differentiation (Witkin and Berry, 1975), cultural patterns (Hsu, 1983), and the self (Jansz, 1991; Markus and Kitayama, 1991; Triandis, 1989).

Initially, individualism and collectivism were perceived as two opposite poles of a one-dimensional scale (Hofstede, 1980, 1983). However, later research results demonstrated that these are autonomous dimensions (Triandis, 1995; Rhee et al., 1996). This means that an individual can get high or low scores in either of these dimensions or high scores in one and low in the other dimension (Rhee et al., 1996).

This study assumes that individualism and collectivism are cultural psychological orientations that include goals, values and beliefs about the vision of the social world, the individual and their identity, the assessment of the social system, and dispositions for behaviour in relation to social objects (Triandis, 1990; Urban, 2008). They are expressed in the psychosocial functioning of the individual (Hofstede and Hofstede, 2007). Individualism determines the individual's tendency to focus on achieving their own goals which do not have to be in line with the group's goals or "socially correct." It involves cost and profit calculation as well as competitiveness assessment (Daab, 1993). The individual's competence is an instrument to achieve the goal, and the way to demonstrate own competences is rivalry or competition with others (Tönnies, 1998). Individually oriented people believe that the self is the basic unit of survival, and have a great need for autonomy (Triandis and Gelfand, 1998). In the literature, individualism used to be associated with chaos, spreading egoism as well as with the individual's tendency to multiply their own potentialities, to increase control over their own life, and responsibility for themselves (Jacyno, 2007; Środa, 2003).

On the other hand, collectivism involves a higher emphasis on the group's goals than personal goals, preferring interdependence with members of one's own group, avoiding emotional distance, and nurturing social relations (Oyserman et al., 2002). Collectively oriented individuals maintain the view that the individual can survive owing to one or several groups (Triandis and Gelfand, 1998). In a culture which highly appreciates collectivist values, the young generation is socialised in such a manner as to make them attach importance to the stability of messages independent of the context, to being economical with expressing emotions and thoughts, and to respect authorities (Jacyno, 2007; Środa, 2003).

The relationship between social orientation and gender in various aspects of an individual's functioning has so far been studied only to a limited extent. However, in the research of Polish academic youth on ethical categories in the value system of an individual due to social orientation, it turned out that individualistic tendencies are much more common among male than female adolescents (Cybal-Michalska, 2017). This is in line with the reports based on extensive research involving representatives of 26 countries on the perception of the stereotype of the male and female roles. Admittedly, at the level of detailed analyses, it turned out that the more individualistic the culture of a given country, the more masculine features related to the individualistic orientation are perceived as male, and that the more collectivistic the culture is, the more collectivist features are attributed to the male pattern. However, in the general assessment, the research findings indicate 
individualistic traits as universally perceived as more masculine than collectivistic traits of the independently dominant sociocultural orientation in different countries (Cuddy et al., 2015). The individualistic vs. collectivistic attitude was also indirectly examined by reference to the values and goals selected as important and implemented by men and women from 20 different nations. It was found that, across different cultures, for both men and women the importance of socioemotional goals increases with the age concerning the need for individualistic achievements. Moreover, differences in the importance of goals indicated as significant by women and men were independent in different countries from the dominant sociocultural orientation. Women pointed to the long-term greater importance of goals and values related to their orientation towards fulfilling a caring and educational role, i.e. indirectly important goals for the community, while men paid more attention to personal goals related to their achievements, professional career, and personal satisfaction. Therefore, the expected intercultural moderation of differences in goals and values important for women and men resulting from the potential gender inequality determined by culture has not been demonstrated (Vilar et al., 2020). This indicates the universal role of gender in defining general goals and values, regardless of the cultural and social orientation of a given nation.

Both individualism and collectivism can occur in the horizontal (emphasising equality) or vertical (emphasising hierarchy) dimensions (Triandis, 1995). The horizontal approach assumes that one self is just as any other "self." The vertical approach, on the other hand, assumes hierarchy, thus one "self" is different from another "self." Based on the horizontal and vertical dimensions, four cultural psychological orientations were distinguished, including horizontal individualism (HI), vertical individualism (VI), horizontal collectivism (HC), and vertical collectivism (VC) (Triandis and Gelfand, 1998). The validity of this division was confirmed by numerous results of research studies carried out e.g. in the United States (Singelis et al., 1995), Taiwan (Yang, 1981), and Korea (Triandis and Gelfand, 1998).

Individuals exhibiting $\mathrm{HI}$ want to be unique and stand out from the group; they are highly autonomous, but not particularly interested in having a higher status than others (Triandis and Gelfand, 1998). Persons with this orientation are looking for individuality rather than distinctiveness. It means that they tend to "take care of their business" and not to compare themselves with others (Triandis and Gelfand, 1998). On the other hand, HI can result in social isolation (Triandis et al., 1988).

VI individuals often want to stand out and achieve a higher status by competing with others (Triandis and Gelfand, 1998). Vertical individualists are particularly interested in comparing themselves with others. They believe that competition is a law of nature, and they want to win in various forms of competition whatever the cost (Triandis and Gelfand, 1998). Persons demonstrating a VI attitude may experience an extreme psychological burden, especially if they fail in their rivalry with others. As a result, the efficiency of their immune system may decrease, and the risk of cardiovascular diseases and immune impairment may increase (Triandis et al., 1988).

HC-oriented individuals consider themselves similar to others and emphasise goals they share with others, interdependence and sociability, but they do not succumb easily to any authority (Triandis and Gelfand, 1998). Horizontal collectivists join in social groups, e.g. families or employees' groups. The well-being of the groups with which they identify is important to them (Triandis and Gelfand, 1998). A higher level of $\mathrm{HC}$ can be observed in collegial groups, such as students. In light of the results of Triandis and Gelfand's research (1998), students were more collectivist horizontally compared to other social groups; they cared more for friendships and relationships than individuals in the general population (Triandis and Gelfand, 1998). The literature seems to suggest that that $\mathrm{HC}$ absorbs the individual's energy in social relations, thus limiting their productivity (Triandis et al., 1988).

In $\mathrm{VC}$, individuals emphasise the integrity of the group; they are willing to sacrifice their personal goals for group goals and support the competitiveness of their group in relation to other groups. This includes subordinating to the will of the authorities representing the group (Triandis and Gelfand, 1998). Vertical collectivists are ready to sacrifice their personal identity for the group they belong to (Triandis and Gelfand, 1998).

Currently, studies investigating adolescents, and considering their views, attitudes, values or social relations, are quite popular among researchers (Urban, 2008). This is related to the fact that these young people are characterised by a high level of involvement in behaviours that are aimed at changing their own "self" and altering the environment, which brings them closer to achieving their own goals and tasks (Bańka, 2005).

\section{CULTURAL PSYCHOLOGICAL ORIENTATIONS AMONG ADOLESCENTS}

It has been observed that the period of adolescence is important for the formation of cultural psychological orientation. Study results have revealed that late adolescence is the "formation phase" for establishing cultural orientations (Vollebergh et al., 2001).

Adolescence is characterised by a strong need for individualism and independence, supported by the process of searching for one's identity. Young people are interested both in searching for their own identity and in manifesting their own attitude towards the world, people, and social problems. The stage of early adolescence is associated with the conventional phase of moral development, in which adolescents are guided by the standards of others, e.g. parents or friends, and which is accompanied by a conviction of the need to respect social values and rules (Kielar-Turska, 2000; Obuchowska, 2000). 
However, these needs are in conflict with the experienced fear of taking responsibility and dependence on relatives (Harwas-Napierała and Trempała, 2004; Miller and Lloyd, 1991). Thus, young people engage in various forms of behaviour in order to overcome the fear of taking responsibility and fulfilling the need for independence. The behaviours in question may include adopting a conformist attitude and turning to collectivism. Therefore, it can be assumed that individualism and collectivism are equally attractive to adolescents, but also represent a psychological burden (Harwas-Napierała and Trempała, 2004). This tendency is consistent with the findings of other authors (CybalMichalska, 2010; Urban, 2008). Urban (2008) argued that it was difficult to unequivocally define individualistic or collectivist preferences in youth.

Based on the findings of studies conducted to date, Polish adolescents appreciate and recognise individualist values such as autonomy and personal agency. On the other hand, the care for their own position and attachment to tradition are less important to them (Cybal-Michalska, 2006). Adolescents in certain areas are collectivist-oriented, e.g. they make their own good dependent on the good of others, treat the family as a source of values, and appreciate cooperation while rejecting rivalry (Cybal-Michalska, 2006).

The studied adolescents declared the need to improve their own abilities, yet in such a way as to take into account the well-being of other people. Students of general secondary schools, high achievers, youth living in big cities, interested in politics and moving freely and easily as tourists, were found to be more individualist oriented (CybalMichalska, 2006). Research conducted by Sabatier et al. (2011) showed that Polish adolescents were also more religious, which had a relatively greater impact on the family orientation of Polish young people and their satisfaction with life. Schwartz et al. (2007) found a higher level of profamily orientation in Poland than in Germany.

Studies exploring the role of cultural psychological orientations for problem solving (Hong, 2009) revealed intercultural differences in the cognitive performance and perception of the problem and in the consequences of its solution to social cognition and behaviour (Nisbett, 2003).

\section{PSYCHOLOGICAL ORIENTATIONS AND COPING WITH STRESS}

Based on the available literature, solving various problems involves varied cognitive processes. Effective problem solving often depends on the consistency between a certain problematic situation and the cognitive processes of the individual trying to solve it. It was observed that social factors as well as individual characteristics of adolescents such as psychological orientation - individualist or collectivist played a significant role in the selection of coping strategies by young people (Kato, 2012; Ogińska-Bulik, 2001; Strus, 2012). The results of studies carried out so far have dem- problems when the solution is rule-based, whereas collectivist-oriented individuals are more effective in solving problems in a specific situational context (Arieli and Sagiv, 2018). Miller (1984) claimed that individuals with the collectivist orientation attached more importance to the context of a situation than individually oriented persons, while assessing the adequacy of behaviour in different situations.

\section{FLEXIBILITY IN COPING WITH STRESS IN ADOLESCENTS}

The situation of stress experienced by the individual is referred to in the literature as a difficult situation. In this context, coping with stress is a sequence of deliberate efforts undertaken as a result of viewing a given situation as a burden. The continuation of these efforts for some time, and their variability, determine the process-oriented nature of coping (Lazarus and Folkman, 1987). One of the key aspects of coping is flexibility in coping with stress (Basińska, 2015). It is expressed in the individual's readiness to carefully monitor the effects of their actions and reflect on their coping, i.e. it assumes a certain level of reflexivity (Vriezekolk et al., 2012). The prerequisite for flexibility in coping is having a relatively wide range of coping strategies. An individual that does not have a repertoire of coping strategies to be used in difficult situations will not be able to change their behaviour, even if they notice the ineffectiveness of the methods applied. The individual's conviction about having a wide repertoire of available strategies reflects their confidence in themselves as to having diverse resources and competences to handle changing circumstances and being able to use these resources adequately in coping with stress (Vriezekolk et al., 2012).

By combining these two assumptions, an attempt was made to show that flexibility in coping with stress depends on the cultural psychological orientation of adolescents. The cognitive processes applied by the individual when making an assessment are neither accidental nor based solely on the specific features of the situation and circumstances. To a large extent, they depend on the psychological orientation resulting from the cultural way of thinking that is available at the time (Hong, 2009; Arieli and Sagiv, 2018).

With age, the frequency of using stress coping strategies related to focusing on the problem, reformulating and reinterpreting the stressor, as well as ignoring the problem increases. Coping in young people becomes more effective over time, as different methods are used to work through the problem. Some adolescents present a vicious cycle in coping with stress, escaping into alcohol or other stimulants. Under stress, younger adolescents tend to listen to music, cry, act out or seek support from significant adults. With age, the ability to anticipate the effects of one's own actions increases, the capacities of logical thinking, planning and adopting the perspective of others increase, as well as the skilful use of experiences - which is reflected in the strategies used (BraunLewensohn et al., 2010; Grzankowska et al., 2019). 
Studies show that the level of coping flexibility in adolescents is lower than in students and adults (Basińska, 2015; Kruczek, 2015) Age-related differences as to the scope of coping flexibility could be explained by differences in the scope of cognitive process (Cheng and Cheung, 2005; Nagase et al., 2009). A change in the manner of thinking takes place during adolescence. Concrete thinking is substituted with abstract thinking and, consequently, adolescents start to develop a valuable skill which lets them identify cause and effect relationships, and predict the consequences of their actions (Zimbardo and Gerrig, 2006). This type of knowledge enables adolescents to monitor stressful situations effectively, assess consequences of dealing with stress, implement diverse strategies, and abandon ineffective strategies stemming from coping flexibility (Kato, 2012).

Because of developmental differences between girls and boys in the process of identity formation, flexibility in coping with stress may also be different (Harwas-Napierała and Trempała, 2002). Some of the research results obtained to date show that girls and boys differ in the type of coping strategies used (Cheng and Furnham, 2002; Compas et al., 2001; Frydenberg and Lewis, 1999). In the studies, girls more frequently than boys declared using strategies consisting in using social support; more often than boys, they talked about their problems, sought advice or consolation. It is also typical for girls than boys to focus on their emotions. Boys, on the other hand, coped with the rebound through sports activity. Older boys more often than girls declared the use of stimulants (Braun-Lewensohn et al., 2010). As far as the flexibility in coping with stress is concerned, the available results indicate no gender differences (Kruczek, 2015). Moreover, no differences in this respect are shown by the results of research conducted by Zong et al. (2010). Seiffge-Krenke (1995) notes that differences in the use of coping strategies become more pronounced with maturation.

The aim of this study was to determine the dominant cultural psychological orientation of the studied Polish youth, identify the role of individualism and collectivism for flexibility in coping and its dimensions, and assess the modifying role of sex and age of the studied adolescents for the relationship between the investigated cultural psychological orientations and flexibility in coping with stress.

\section{HYPOTHESES}

Based on the body of research discussed above, four competing hypotheses exist to be explored:

- H1: It is assumed that the sex of adolescents differentiates the subjects in terms of cultural psychological orientation. Individualistic tendencies are expected to occur more commonly in boys than in girls. On the other hand, collectivist attitudes are associated with girls rather than boys.

- H2: It is assumed that there are links between cultural psychological orientations and flexibility in coping with stress and its dimensions. Both the psychological orientation of $\mathrm{HC}$ and $\mathrm{HI}$ in adolescents will be positively related to flexibility in coping with stress.

- H3: Cultural psychological orientations are predictors of flexibility in coping. The individualist orientation will foster higher flexibility in coping than the collectivist orientation.

- H4: Relationships between the orientations of individualism and collectivism and flexibility in coping will be modified by the age and sex of the adolescents under study.

\section{MATERIALS AND METHODS}

\section{Participants}

A total of 367 Polish adolescents (131 boys and 236 girls) in the age range from 13 to 20 years were qualified for the study. The mean age in the study group was $M_{\text {age }}=17.26$ (standard deviation, $S D=1.90)$. The boys $\left(M_{\text {age }}=16.67\right.$, $S D=1.77)$ and girls $\left(M_{\text {age }}=17.61, S D=1.89\right)$ differed significantly in terms of age $(t=4.63, p<0.001)$, as the girls were older. The adolescents came from villages ( $n=149,40 \%)$, large cities inhabited by the population of up to 400,000 inhabitants ( $n=93,25 \%)$, from cities inhabited by the population of up to 100,000 inhabitants $(n=88,23 \%)$ and from towns inhabited by the population of up to 25,000 inhabitants $(n=38,10 \%)$.

\section{Materials and procedure}

The study was based on the Individualism-Collectivist Questionnaire by Harry Triandis and Michele Gelfand (1998) in the Polish adaptation of Basińska et al. (in press), which consists of 16 items. It measures cultural psychological orientations: VI, i.e. perceiving oneself as a fully autonomous person, but recognising that there are diverse inequalities among individuals and it is important for this person to compete with others $(\alpha=0.69)$; HI, i.e. perceiving oneself as a fully autonomous and independent person; this person is convinced to have a relatively equal status with other members of the group ( $\alpha=0.69)$; VC, i.e. the person assumes that some members of the group to which they belong have a higher status than others in the same group ( $\alpha=0.78$ ); and $\mathrm{HC}$, that is, perceiving oneself as part of a group and recognising other members as equal; the person emphasises their own similarity to the group members and equality with them $(\alpha=0.65)$. The person studied can respond to the 9-point scale starting from 1 - definitely not, to 9 - definitely yes.

The Flexibility in Coping with Stress Questionnaire for Adolescents - 14 (FCQ-14A) consists of 14 items. The questionnaire in its version adapted for young people (age range from 14 to 20 years) consists of three subscales: changeability - which examines the tendency to use those coping strategies that ensure effective solving of a difficult situation; when a person notices that the applied method is 


\begin{tabular}{|c|c|c|c|c|c|c|c|c|c|c|}
\hline \multirow{2}{*}{$\begin{array}{l}\text { Cultural psychological } \\
\text { orientations }\end{array}$} & \multirow[t]{2}{*}{$M$} & \multirow[t]{2}{*}{ SD } & \multirow[t]{2}{*}{ SKE } & \multirow[t]{2}{*}{ K } & \multicolumn{2}{|c|}{$\begin{array}{c}\text { Girls } \\
(n=236)\end{array}$} & \multicolumn{2}{|c|}{$\begin{array}{c}\text { Boys } \\
(n=131)\end{array}$} & \multirow[t]{2}{*}{$t$} & \multirow[t]{2}{*}{$p$} \\
\hline & & & & & $M$ & SD & $M$ & SD & & \\
\hline Horizontal individualism & 24.68 & 5.45 & -0.25 & 0.18 & 24.84 & 5.42 & 24.54 & 5.54 & 0.32 & 0.750 \\
\hline Vertical individualism & 20.05 & 6.56 & 0.32 & 0.29 & 18.33 & 6.09 & 21.27 & 6.65 & -2.70 & 0.008 \\
\hline Horizontal collectivism & 26.44 & 6.30 & -0.52 & -0.01 & 27.17 & 5.94 & 25.86 & 6.58 & 1.21 & 0.228 \\
\hline Vertical collectivism & 27.96 & 6.46 & -0.96 & 0.89 & 29.13 & 5.98 & 27.03 & 6.70 & 1.93 & 0.056 \\
\hline
\end{tabular}

Tab. 1. Average intensity of cultural psychological orientations of adolescents $(\mathrm{N}=367)$

\begin{tabular}{|l|c|c|c|c|}
\hline Variables & Changeability & Coping competences & Reflexivity & Flexibility in coping \\
\hline Horizontal individualism & $0.34^{* * *}$ & $0.27^{* *}$ & $0.33^{* * *}$ & $0.34^{* * *}$ \\
\hline Vertical individualism & 0.15 & 0.11 & 0.11 & 0.14 \\
\hline Horizontal collectivism & $0.24^{* *}$ & 0.17 & $0.25^{* *}$ & $0.25^{* *}$ \\
\hline Vertical collectivism & $0.21^{*}$ & 0.09 & $0.22^{*}$ & $0.19^{*}$ \\
\hline${ }^{*} p<0.05^{* *} p<0.01{ }^{* * *} p<0.001$. & &
\end{tabular}

Tab. 2. Relationships between psychological orientations and flexibility in coping with stress $(\mathrm{N}=367)$

ineffective, he/she changes it, looking for a more relevant way of coping ( $\alpha=0.87$ ); coping competences - this examines the individual's conviction of being able to find adequate remedies and apply them when necessary; concerns the perception of oneself as a competent person in the field of coping ( $\alpha=0.69$ ); reflexivity which refers to the situation when the individual is willing to give themselves time and think about the way of coping they use, and to reflect on the strategy applied in the context of values important to them, and accept the emergent situation $(\alpha=0.72)$. It is possible to calculate the overall result in terms of flexibility in coping with stress $(\alpha=0.89)$ (Grzankowska et al., 2019). A personal survey was used to collect sociodemographic information.

\section{Procedure}

The study procedure: the selection of respondents was targeted, with adolescents at various stages of education recruited for the study. Questionnaire packages - whose order in the package was rotated - were used. The study was of a group nature. All statistical analyses were performed using the SPSS software. The normality of variable distributions was verified, and relevant analyses were applied. All subscales were characterised by an acceptable Cronbach's a coefficient, i.e. close to 0.70 (Nunnally, 1978).

\section{RESULTS}

\section{Dominant cultural psychological orientation of Polish adolescents}

The study results show that the examined adolescents achieved the highest mean scores in the psychological orientation of VC (Tab. 1). It differed significantly from other types of orientation, from the intensity of VI and HI $(p<0.0001)$, and from HC $(p=0.0013)$ as well. Statistically significant differences in VI due to the sex of the respondents were observed. The boys displayed a higher level of VI than the girls (Tab. 1).

\section{Relationships between cultural psychological orientations and flexibility in coping with stress and its dimensions}

There were statistically significant positive correlations between $\mathrm{HI}$ and flexibility in coping with stress and its dimensions. The more individually horizontally oriented the adolescents were, the more flexible they were in coping with stress; they were more variable in applying coping strategies, they had higher coping competence and higher reflexivity levels. No such correlations with VI were observed. Moreover, the results of the analyses show that statistically

\begin{tabular}{|c|c|c|c|c|c|}
\hline \multirow{2}{*}{ Predictors } & \multicolumn{2}{|c|}{ Non-standard coefficients } & \multirow{2}{*}{$\begin{array}{c}\text { Standard coefficients } \\
\beta \\
\end{array}$} & \multirow{2}{*}{$t$} & \multirow{2}{*}{$p$} \\
\hline & $B$ & SE & & & \\
\hline Horizontal individualism & 0.29 & 0.09 & 0.43 & 3.11 & 0.002 \\
\hline Vertical individualism & -0.01 & 0.09 & -0.01 & -0.03 & 0.979 \\
\hline Horizontal collectivism & 0.16 & 0.11 & 0.20 & 1.45 & 0.150 \\
\hline Vertical collectivism & 0.01 & 0.11 & 0.01 & 0.03 & 0.979 \\
\hline
\end{tabular}




\begin{tabular}{|c|c|c|c|c|c|}
\hline \multirow{2}{*}{ Predictors } & \multicolumn{2}{|c|}{ Non-standard coefficients } & \multirow{2}{*}{$\begin{array}{c}\text { Standard coefficients } \\
\beta\end{array}$} & \multirow[b]{2}{*}{$t$} & \multirow[b]{2}{*}{$p$} \\
\hline & $B$ & SE & & & \\
\hline Horizontal individualism & 0.23 & 0.09 & 0.17 & 2.48 & 0.014 \\
\hline Vertical individualism & 0.02 & 0.09 & 0.01 & 0.21 & 0.831 \\
\hline Horizontal collectivism & 0.16 & 0.11 & 0.10 & 1.46 & 0.145 \\
\hline Vertical collectivism & 0.04 & 0.11 & 0.02 & 0.34 & 0.737 \\
\hline
\end{tabular}

Tab. 4. Predictive role of cultural psychological orientations for strategy variation $(\mathrm{N}=367)$

\begin{tabular}{|l|c|c|c|c|c|}
\hline \multirow{2}{*}{ Predictors } & Non-standard coefficients & Standard coefficients & \multirow{2}{*}{$\boldsymbol{t}$} & \multirow{2}{*}{$\boldsymbol{p}$} \\
\cline { 2 - 5 } & $\boldsymbol{B}$ & $\boldsymbol{S E}$ & $\boldsymbol{\beta}$ & 2.72 & 0.007 \\
\hline Horizontal individualism & 0.26 & 0.10 & 0.11 & 0.03 & 0.978 \\
\hline Vertical individualism & 0.01 & 0.09 & 0.01 & 1.19 & 0.237 \\
\hline Horizontal collectivism & 0.13 & 0.11 & 0.05 & -0.65 & 0.515 \\
\hline Vertical collectivism & -0.07 & 0.11 & -0.03 & \\
\hline$F(4,368)=3.16, p=0.016, R^{2}=0.09, R^{2}$ corrected $=0.06$.
\end{tabular}

Tab. 5. Predictive role of cultural psychological orientations for coping competences $(\mathrm{N}=367)$

significant positive relationships between $\mathrm{HC}$ and $\mathrm{VC}$ and flexibility in coping with stress and its two dimensions changeability and reflexivity - can be observed. The more collectivist the adolescents were - either horizontally or vertically - the more flexible they were in coping with stress. In addition, they were more variable in the application of coping strategies and more reflective (Tab. 2).

\section{Predictive role of cultural psychological orientations for flexibility in coping with stress and its dimensions}

The data analysis showed that the psychological orientation of $\mathrm{HI}$ was a predictor of flexibility in coping with stress among the Polish adolescents. The more horizontally individualist the adolescents were, the more flexible they were in coping with stress (Tab. 3 ).

The data analysis showed that the psychological orientation of HI was also a predictor of the variability of applying coping strategies in the adolescents under study. The more horizontally individualist they were, the more variable they were in applying coping strategies (Tab. 4).

The data analysis showed that the psychological orientation of HI was a predictor for the coping competences of adolescents. The more horizontally individualist they were, the higher level of coping competence they had (Tab. 5).
The data analysis showed that the psychological orientation of HI was a predictor of the coping competences of adolescents. They were characterised by higher reflexivity when they were more individualist horizontally (Tab. 6).

\section{Modifying role of age and sex for the relationship between the individualist and collectivist orientations and flexibility in coping}

H4 assumed that the sociodemographic variables of adolescents (sex and age) act as modifiers for the relationship between cultural psychological orientations (HI and VI, HC and VC) and flexibility in coping with stress and its dimensions.

The general modification scheme for H4 is shown in Fig. 1.

\section{Relationship between $\mathrm{HI}$ and flexibility in coping with stress and its dimensions - the modifying role of sex}

We assumed that sex acts as a modifier between the psychological orientation of $\mathrm{HI}$ and flexibility in coping with stress and its dimensions among adolescents. On the basis of our analyses, only simple effects between $\mathrm{HI}$ and flexibility in coping, $F(3.368)=7.81, p<0.001, R^{2}=0.15, B=-0.26$, $p=0.235,95 \%$ confidence interval, CI $[-0.728,0.202]$;

\begin{tabular}{|c|c|c|c|c|c|}
\hline \multirow{2}{*}{ Predictors } & \multicolumn{2}{|c|}{ Non-standard coefficients } & \multirow{2}{*}{$\begin{array}{c}\text { Standard coefficients } \\
\beta \\
\end{array}$} & \multirow{2}{*}{$t$} & \multirow{2}{*}{$p$} \\
\hline & $B$ & SE & & & \\
\hline Horizontal individualism & 0.25 & 0.10 & 0.12 & 2.63 & 0.010 \\
\hline Vertical individualism & -0.03 & 0.09 & -0.01 & -0.30 & 0.766 \\
\hline Horizontal collectivism & 0.15 & 0.11 & 0.06 & 1.33 & 0.185 \\
\hline Vertical collectivism & 0.03 & 0.11 & 0.01 & 0.30 & 0.766 \\
\hline
\end{tabular}

Tab. 6. Predictive role of cultural psychological orientations for reflexivity over coping $(\mathrm{N}=367)$ 


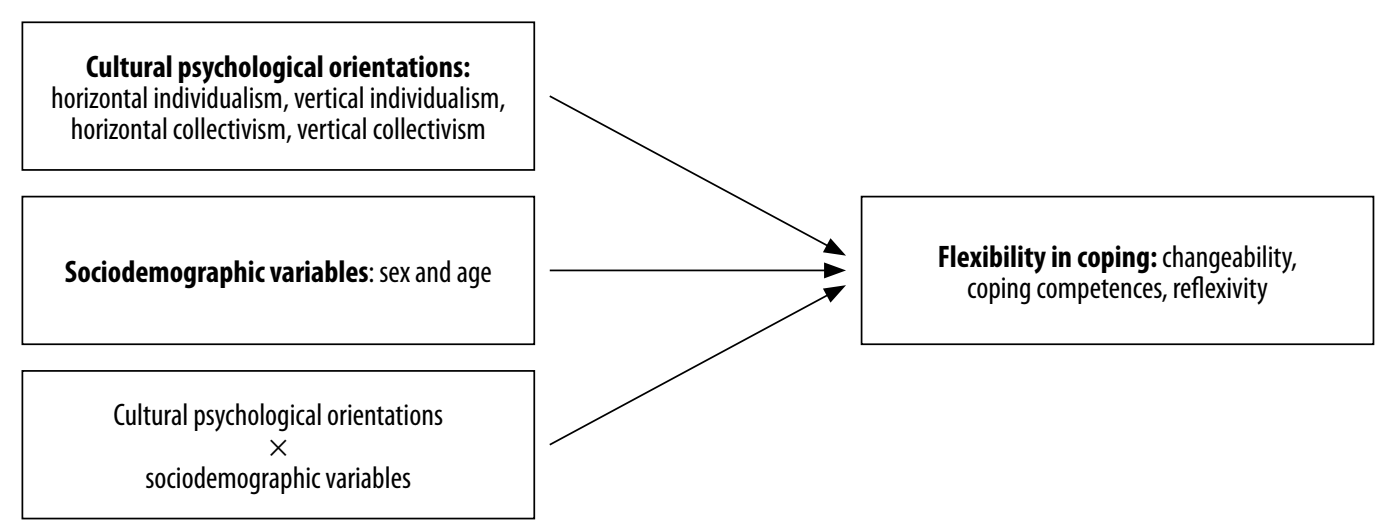

Fig. 1. Analysis of modification for cultural psychological orientation, gender, and age of adolescents in the context of flexibility in coping with stress

variability, $F(3.368)=6.33, p<0.001, R^{2}=0.12, B=-0.14$, $p=0.240,95 \%$ CI $[-367,0.093]$; coping competences, $F(3.368)=6.49, p<0.001, R^{2}=0.12, B=-0.09, p=0.159$, $95 \%$ CI $[-0.238,0.039]$ and reflexivity, $F(3.368)=4.63$, $p=0.004, R^{2}=0.09, B=-0.06, p=0.407,95 \%$ CI $[-0.228$, 0.092] were demonstrated.

\section{Relationship between $\mathrm{HI}$ and flexibility in coping with stress and its dimensions - the modifying role of age}

We assumed that the age of adolescents acts as a modifier between the psychological orientation of HI and flexibility in coping with stress and its dimensions. On the basis of our analyses, only simple effects between $\mathrm{HI}$ and coping flexibility, $F(3.368)=6.80, p=0.003, R^{2}=0.13$, $B=-0.09, p=0.070,95 \%$ CI [ $0.186,0.007]$; variability, $F(3.368)=4.80, p=0.003, R^{2}=0.10, B=-0.03, p=0.192$, $95 \%$ CI $[-0.081,0.016]$ and reflexivity, $F(3.368)=4.18$, $p=0.007, R^{2}=0.09, B=-0.02, p=0.358,95 \%$ CI $[-0.49$, 0.018] were found. A significant interaction effect (Tab. 7) was observed only for the coping competences.

The analysis revealed that the model for the relationship between $\mathrm{HI}$ and coping competences with the modifying role of age was statistically significant, $F(3.368)=6.31, p=0.003$ and accounted for $12 \%$ of variability of adolescents' coping competences; $B=-0.04, p=0.013,95 \%$ CI $[-0.065$, -0.008] (Tab. 7). We demonstrated on the basis of Johnson-Neyman's technique that when adolescents in the age range from 13 to 17 years were more horizontally individually oriented, they manifested superior coping competences, whereas in the group of older adolescents (>17.4) this effect was not identified.

\section{DISCUSSION}

The results of research published to date show that the individual's internalised cultural orientation is, in addition to personality, experience, and other psychological processes, a very important factor among the determinants of the individual's behaviour (Markus and Kitayama, 1991; Triandis, 1995, 2001). Preferences related to stressing individualism or collectivism in functioning are among vital factors modelling behaviour in specific situations, including stressful circumstances (Arieli and Sagiv, 2018; Kato, 2012; Ogińska-Bulik, 2001; Strus, 2012) due to their relationship with the functioning of the individual in many aspects: cognitive, emotional or motivational (Hofstede and Hofstede, 2007; Markus and Kitayama, 1991). Persons representing each of these orientations have been found to function differently in specific life situations (LeFebvre and Franke, 2013; Triandis and Gelfand, 1998).

In the present study, we determined the characteristics of the psychological cultural orientation of the Polish youth, with the dominant role of preferences towards VC, which implies that this population puts a high value on the integrity of the group, declares their readiness and willingness to sacrifice personal goals for group goals, including the readiness

\begin{tabular}{|c|c|c|c|c|c|c|}
\hline \multirow{2}{*}{ Effects } & \multirow{2}{*}{ B } & \multirow{2}{*}{ SE } & \multirow{2}{*}{$t$} & \multirow{2}{*}{$p$} & \multicolumn{2}{|c|}{$95 \% \mathrm{Cl}$} \\
\hline & & & & & LL & UL \\
\hline Horizontal individualism & 0.72 & 0.238 & 3.03 & 0.003 & 0.250 & 0.191 \\
\hline Age (1 = younger adolescents, 2 = older adolescents) & 0.82 & 0.362 & 2.26 & 0.025 & 0.102 & 1.533 \\
\hline Interaction & -0.04 & 0.015 & -2.52 & 0.013 & -0.065 & -0.008 \\
\hline
\end{tabular}


to subordinate to the will of the authority recognised by the group. At the same time, VC provides protection and safety to the individual, also by reducing the need to make decisions, which may be a form of protection against anxiety (Triandis and Gelfand, 1998). However, this result is partially different from that obtained by Cybal-Michalska (2017) who found that Polish adolescents appreciate individualist values more, such as autonomy and personal agency, while at the same time they care less for their own status and attachment to tradition. This discrepancy may suggest that perhaps these two cultural perspectives coexist and do not have to be in opposition to each other in the concept of the world and themselves that the young Poles have. It should be noted that in the literature on this topic collectivism should not be seen as the opposite of individualism (Realo et al., 1997). Researchers seem to agree with the claim that one person or group may be more collectivist in a specific situation, and less collectivist in another (Matsumoto et al., 1996; Oyserman, 2017; Realo et al., 1997). Taking into account the development stage of the adolescents, it may be important to distinguish three different interrelated subtypes of collectivism in order to understand the variability of results. Primarily, family collectivism (infamilism) is essential, focusing on relationships with the family and implying sacrificing life for the family and putting family interests higher than personal aspirations. It also applies to ensuring family safety, and at the same time honouring parents and the elderly (Realo et al., 1997). In turn, companionship collectivism is characterised by close relationships between the individual and their neighbours, friends or colleagues, and is related to the orientation to the needs of their group (Realo et al., 1997). The last form of collectivism is patriotism which, in this approach, means dedicating oneself to one's own nation by sacrificing personal comfort for serving the country. Patriots are always ready to make sacrifices and defend their nation against their enemies (Matsumoto et al., 1996; Realo et al., 1997). It is difficult to assume which of these collectivist perspectives is important for a young person who, after all, is in a period of development associated with identifying and building the integrity of the self (Cybal-Michalska, 2006). In previous studies, it was found that, for example, the religiousness of Polish teenagers is higher than that of other nationalities, as indicated by Sabatier et al. (2011). The authors attributed this observation to a stronger family orientation and greater satisfaction with life in this group of respondents. On the one hand, a young person, being so immersed in the psychosocial world of values related to the family and religiousness that are quite powerfully and explicitly expressed in the Polish culture, develops the collectivist orientation. Yet, concurrently, in this period of life an essential development need is to stand out and individualise functioning (Brzezińska et al., 2008); this need may be revealed in the inconsistency of research results and scholarly observations. In this situation, values perceived as major elements of culture may not be identical with the viewpoints held, and this discrepancy is typical of younger persons (Fung et al., 2016).
The results obtained in the study indicate that individualism exhibits a relationship with the sex of the studied adolescents. The examined boys manifested a higher level of VI than girls. According to other reports discussing the attitude of women towards relationships, young boys want to stand out more in their group and are even willing to isolate themselves to feel and manifest their distinctiveness (Triandis and Gelfand, 1998). However, this is related to experiencing the effects of social isolation, and with the limitation of available or experienced support. It is recognised, however, that a higher level of support is associated with more positive indicators of the individual's functioning (Napora, 2019; Wei et al., 2012). The access to support, limited by isolation, may therefore result in less effective functioning. The literature also shows that individuals with the VI orientation put an emphasis on competition. A negative aspect of this psychological attitude is experiencing greater mental strain, which results, among others, in increased tiredness (Triandis and Gelfand, 1998). The research results indicate the absence of any correlation between the VI orientation and flexibility in coping with stress and its dimensions. Combined with the tendency to isolation, it appears to be a potential risk factor for the development of symptoms of excessive burden and exhaustion in this group. It turned out, however, that positive relationships between $\mathrm{HI}$ and flexibility in coping with stress and its dimensions could be observed. Earlier reports indicated the ability of such individuals to perceive the self as stable and the social environment as variable. As a consequence of this perception, persons manifesting $\mathrm{HI}$ tend to shape the social environment so it would fit their personality (Triandis, 1995), so they can be described as flexible. Moreover, it was demonstrated that younger adolescents who were more horizontally individually oriented (age range from 13 to 17 year) had higher coping competences, whereas in the group of older adolescents ( $>17.4)$ this effect did not occur.

The data analysis also showed that the psychological orientation towards HI was a predictor of flexibility in coping with stress and its dimensions in adolescents. When adolescents were more horizontally individually oriented, they were more likely to cope with stress in a more flexible way. They exhibited higher variability in the use of coping strategies; they were convinced that they had higher coping competences and manifested higher reflexivity. In order to explain the predictive role of $\mathrm{HI}$ for flexibility in coping with stress and its dimensions, it is worth referring to its definition which states that horizontal individualists are able to achieve their goals without feeling restricted by any imposed group goals (Triandis and Gelfand, 1998). At the same time, the attitude towards coexistence, rather than competition, probably makes them seek ways to limit the occurrence of situations that are difficult in the interpersonal perspective, which requires certain efforts to monitor their own behaviours. This promotes the development of competences for flexible coping (Basińska and Rusek, 2015). 
In the reported study, however, there no relationship was observed between the VI orientation and flexibility in coping with stress and its dimensions. Other authors highlight that individuals with the VI orientation put emphasis on competition. A negative aspect of this orientation is experiencing mental strain, including tension (Triandis and Gelfand, 1998). The absence of correlations with flexibility in coping indicates the particularly burdensome nature of individualist orientation in its vertical form due to limited resources of the individual with such orientation to handle difficult situations.

A concurrent collectivist orientation could have a protective effect for persons with the psychological VI orientation (Realo et al., 1997), because the results of the presented research reveal positive relationships between $\mathrm{HC}$ and VC and flexibility in coping with stress and its dimensions, i.e. changeability and reflexivity. More horizontally or vertically collective adolescents were found to cope with stress in a more flexible way, and manifested greater variability in the application of coping strategies and reflexivity. Individuals with the collectivist orientation, both horizontal and vertical, experience greater social support, as they are much more sociable (Triandis and Gelfand, 1998). The openness to develop and build relationships with others can also be an opportunity to learn from others new variants of coping strategies to manage difficulties, which ultimately enriches the repertoire of coping strategies and expands the range of available strategies.

To sum up the above considerations, it is worth referring to the theory of culture that situates cognition (culture-assituated-cognition), which adopts a broader perspective in defining individualism and collectivism. Individuals can change their own cultural orientation and come closer to another in their own way of thinking. This is particularly important in the case of the VI orientation that is unfavourable to health. If it was possible to reformulate this perspective - or enhance it with features of cultural orientation syndromes that are associated with flexibility in coping this could facilitate better functioning of these persons. The assumption on the possibility of changing the orientation in this approach is based on the basic rationale that even though societies differ in the influences of individualism-collectivism, they include both principles of individualism and collectivism. This reflects the pursuit to achieve two goals: group goals, i.e. ensuring the survival of the group, pursuing group goals, and regulating relationships between individuals, and individual goals related to encouraging the expression of free choice and the individual's uniqueness (Oyserman, 2017; Ozer et al., 2019; Schwartz et al., 2007; Triandis, 1995).

Another approach, which also takes into account the possibility of changing the cultural orientation, assumes the belief that the individual, recognising the rate and intensity of changes in the surrounding world, tries to be an active subject of changes taking place in the cultural and social contexts. which directions others move, and what changes they are subject to (Cybal-Michalska, 2006). This may include the perception of cultural orientation. It gives individuals an opportunity to revise and change their convictions in a manner enabling them to cope more effectively with difficulties. However, it can be challenging for persons with the VI orientation to learn and transform, as they perceive others as competing individuals or individuals that must be competed with. Their conviction about their own or someone else's higher social status poses a risk of limiting motivation for social learning (Bandura, 2015; Brzezińska, 2000).

\section{SUMMARY AND CONCLUDING REMARKS}

It appeared that the majority of initial assumptions adopted for the purpose of the study were confirmed. Indeed, it turned out that:

1. The sex of adolescents differentiates the respondents in terms of psychological orientation, with boys being more vertically individually oriented than girls.

2. Both VC and HC orientation are related to flexibility in coping and its dimensions, similarly as the individualist horizontal orientation.

3. The individualist orientation, but only in the horizontal variant, is a predictor of flexibility in coping and its dimensions.

4. Relationships between cultural orientations - individualism and collectivism - were found to be modified only by the age of the adolescents under study. The sex did not modify this relationship.

The presented research results are an important contribution to the recognition and acknowledgement of flexibility in coping, but they also address numerous questions about its relationship with the cultural orientation.

\section{Conflict of interest}

The authors do not report any financial or personal affiliations to persons or organisations that could adversely affect the content of or claim to have rights to this publication.

\section{Funding/Support and role of the sponsor}

This research was supported by grants from the National Science Centre, Poland, research project: OPUS 11, No.: DEC-2016/21.

\section{References}

Allik J, Realo A: Individualism-collectivism and social capital. J Cross Cult Psychol 2004; 35: 29-49.

Arieli S, Sagiv L: Culture and problem-solving: congruency between the cultural mindset of individualism versus collectivism and problem type. J Exp Psychol Gen 2018; 147: 789-814.

Bandura A: On deconstructing commentaries regarding alternative theories of self-regulation. J Manage 2015; 41: 1025-1044.

Bańka A: Proaktywność a tryby samoregulacji. Podstawy teoretyczne, konstrukcja i analiza czynnikowa Skali Zachowań Proaktywnych w Karierze. Stowarzyszenie Psychologia i Architektura, Poznań-Warszawa 2005. 
Basińska MA (ed.): Elastyczne radzenie sobie ze stresem w zdrowiu i w chorobie. Wydawnictwo UKW, Bydgoszcz 2015.

Basińska MA, Rusek A: Temperament and coping flexibility in a group of art students / Temperament a elastyczne radzenie sobie ze stresem w grupie studentów kierunków artystycznych. In: Basińska MA (ed.): Coping Flexibility with Stress in Health and in Disease / Elastyczne radzenie sobie ze stresem $\mathrm{w}$ zdrowiu i w chorobie. Wydawnictwo UKW, Bydgoszcz 2015: 117-132.

Braun-Lewensohn O, Sagy S, Roth G: Coping strategies among adolescents: Israeli Jews and Arabs facing missile attacks. Anxiety Stress Coping 2010; 23: 35-51.

Brzezińska A: Społeczna psychologia rozwoju. SCHOLAR, Warszawa 2000.

Brzezińska AI, Appelt K, Ziółkowska B: Psychologia rozwoju człowieka. In: Strelau J, Doliński D (eds.): Psychologia. Podręcznik akademicki. Vol. 2, Gdańskie Wydawnictwo Psychologiczne, Gdańsk 2008: 95-292.

Cheng C, Cheung MWL: Cognitive processes underlying coping flexibility: differentiation and integration. J Pers 2005; 73: 859-886.

Cheng C, Furnham A: Personality, peer relations, and self-confidence as predictors of happiness and loneliness. J Adolesc 2002; 25: 327-339.

Compas BE, Connor-Smith JK, Saltzman H et al.: Coping with stress during childhood and adolescence: problems, progress, and potential in theory and research. Psychol Bull 2001; 127: 87-127.

Cuddy AJC, Wolf EB, Glick P et al.: Men as cultural ideals: cultural values moderate gender stereotype content. J Pers Soc Psychol 2015; 109: 622-635.

Cybal-Michalska A: „Indywidualistyczne” vs „kolektywistyczne” orientacje normatywne młodzieży akademickiej. Studia Edukacyjne 2017; 45: 7-17.

Cybal-Michalska A: Społeczeństwo przyszłości w wyobrażeniach młodzieży: indywidualistyczna vs. kolektywistyczna koncepcja społeczeństwa. In: Melosik Z, Śliwerski B (eds.): Edukacja alternatywna w XXI wieku. Oficyna Wydawnicza „Impuls”, Kraków 2010:315-332.

Cybal-Michalska A: Tożsamość młodzieży w perspektywie globalnego świata. Studium socjopedagogiczne. Wydawnictwo Naukowe Uniwersytetu im. Adama Mickiewicza, Poznań 2006.

Daab WZ: Indywidualizm a poglądy społeczno-polityczne. In: Reykowski J (ed.): Wartości i postawy Polaków a zmiany systemowe. Szkice z psychologii politycznej. Wydawnictwo Instytutu Psychologii PAN, Warszawa 1993: 101-128.

Fijneman YA, Willemsen ME, Poortinga YH: Individualism-collectivism: an empirical study of a conceptual issue. J Cross Cult Psychol 1996; 27: 381-402.

Frydenberg E, Lewis R: Academic and general well-being: the relationship with coping. Australian Journal of Guidance and Counselling 1999; 9: 19-36.

Fung HH, Ho YW, Zhang R et al.: Age differences in personal values: universal or cultural specific? Psychol Aging 2016; 31: 274-286.

Grzankowska I, Kruczek A, Sołtys M et al.: Kwestionariusz Elastyczności w Radzeniu Sobie ze Stresem dla Adolescentów (KERS-14A). Psychologia Rozwojowa 2019; 24: 39-56.

Harwas-Napierała B, Trempała J (eds.): Psychologia rozwoju człowieka. Vol. 2: Charakterystyka okresów życia człowieka. Wydawnictwo Naukowe PWN, Warszawa 2004.

Harwas-Napierała B, Trempała J (eds.): Psychologia rozwoju człowieka. Vol. 3: Rozwój funkcji psychicznych. Wydawnictwo Naukowe PWN, Warszawa 2002.

Hofstede G: Culture’s Consequences: International Differences in WorkRelated Values. SAGE Publications, Beverly Hills/London 1980.

Hofstede G: National cultures revisited. Cross Cult Res 1983; 18: 285-305.

Hofstede G, Hofstede GJ: Kultury i organizacje. Polskie Wydawnictwo Ekonomiczne, Warszawa 2007.

Hong Yy: A dynamic constructivist approach to culture: moving from describing culture to explaining culture. In: Wyer RS, Chiu Cy, Hong Yy (eds.): Understanding Culture: Theory, Research, and Application. Psychology Press, New York 2009: 3-23.

Hsu FLK: Rugged Individualism Reconsidered. University of Tennessee Press, Knoxville 1983.

Jacyno M: Kultura indywidualizmu. Wydawnictwo Naukowe PWN, Warszawa 2007.
Jansz J: Person, Self, and Moral Demands: Individualism Contested by Collectivism. DSWO Press, Leiden 1991.

Kagitcibasi C, Ataca B: Value of children and family change: a threedecade portrait from Turkey. Appl Psychol 2005; 54: 317-337.

Kato T: Development of the Coping Flexibility Scale: evidence for the coping flexibility hypothesis. J Couns Psychol 2012; 59: 262-273.

Keller H, Lamm B: Parenting as the expression of sociohistorical time: the case of German individualisation. Int J Behav Dev 2005; 29 : 238-246.

Kielar-Turska M: Rozwój człowieka w pełnym cyklu życia. In: Strelau J (ed.): Psychologia. Podręcznik akademicki. Vol. 1, Gdańskie Wydawnictwo Psychologiczne, Gdańsk 2000: 285-332.

Kim U, Triandis HC, Kâğıtçıbaşı Ç et al. (eds.): Individualism and Collectivism: Theory, Method, and Applications. SAGE Publications, Newbury Park 1994.

Kruczek A: Emotion control and anger expression style in relation to coping flexibility in groups of college students and high school students / Kontrola gniewu a elastyczne radzenie sobie ze stresem w grupie młodzieży szkół gimnazjalnej i ponadgimnazjalnej. In: Basińska MA (ed.): Coping Flexibility with Stress in Health and in Disease / Elastyczne radzenie sobie ze stresem w zdrowiu i w chorobie. Wydawnictwo UKW, Bydgoszcz 2015: 95-116.

Lazarus RS, Folkman S: Transactional theory and research on emotions and coping. Eur J Pers 1987; 1: 141-169.

LeFebvre R, Franke V: Culture matters: individualism $v$ s. collectivism in conflict decision-making. Societies 2013; 3: 128-146.

Markus HR, Kitayama S: Culture and the self: Implications for cognition, emotion, and motivation. Psychol Rev 1991; 98: 224-253.

Matsumoto D, Kudoh T, Takeuchi S: Changing patterns of individualism and collectivism in the United States and Japan. Cult Psychol 1996; 2: 71-107.

Miller JG: Culture and development of everyday social explanation. J Pers Soc Psychol 1984; 46: 961-978.

Miller PM, Lloyd C: Social support and its interactions with personality and childhood background as predictors of psychiatric symptoms in Scottish and American medical students. Soc Psychiatry Psychiatr Epidemiol 1991; 26: 171-177.

Nagase Y, Uchiyama M, Kaneita Y et al.: Coping strategies and their correlates with depression in the Japanese general population. Psychiatry Res 2009; 168: 57-66.

Napora E: Relacje w rodzinie samotnej matki. Znaczenie wsparcia od dziadków dla komunikowania się z rówieśnikami. Wydawnictwo Uniwersytetu Humanistyczno-Przyrodniczego im. Jana Długosza, Częstochowa 2019.

Nisbett RE: The Geography of Thought: How Asians and Westerners Think Differently... and Why. Free Press, New York 2003.

Nunnally JC: Psychometric Theory. $2^{\text {nd }}$ ed., McGraw-Hill, New York 1978.

Obuchowska I: Adolescencja. In: Harwas-Napierała B, Trempała J (eds.): Psychologia rozwoju człowieka. Vol. 2: Charakterystyka okresów życia człowieka. Wydawnictwo Naukowe PWN, Warszawa 2000: 163-201.

Ogińska-Bulik N: Zasoby osobiste jako wyznaczniki radzenia sobie ze stresem u dzieci. Acta Universitatis Lodziensis. Folia Psychologica 2001; 5: 83-93.

Oyserman D: Culture three ways: culture and subcultures within countries. Annu Rev Psychol 2017; 68: 435-463.

Oyserman D, Coon HM, Kemmelmeier M: Rethinking individualism and collectivism: Evaluation of theoretical assumptions and metaanalyses. Psychol Bull 2002; 128: 3-72.

Ozer S, Meca A, Schwartz SJ: Globalization and identity development among emerging adults from Ladakh. Cultur Divers Ethnic Minor Psychol 2019; 25: 515-526.

Parsons T, Shils EA (eds.): Toward a General Theory of Action. Harvard University Press, Cambridge 1951.

Realo A, Allik J, Vadi M: The hierarchical structure of collectivism. J Res Pers 1997; 31: 93-116.

Rhee E, Uleman JS, Lee HK: Variations in collectivism and individualism by ingroup and culture: confirmatory factor analyses. J Pers Soc Psychol 1996; 71: 1037-1054. 
Sabatier C, Mayer B, Friedlmeier M et al.: Religiosity, family orientation, and life satisfaction of adolescents in four countries. J Cross Cult Psychol 2011; 42: 1375-1393.

Schwartz SJ, Zamboanga BL, Rodriguez L et al.: The structure of cultural identity in an ethnically diverse sample of emerging adults. Basic Appl Soc Psych 2007; 29: 159-173.

Seiffge-Krenke I: Stress, Coping and Relationships in Adolescence. Lawrence Erlbaum Association, Mahwah 1995.

Silbereisen RK: Social change and human development: experiences from German unification. Int J Behav Dev 2005; 29: 2-13.

Singelis TM, Triandis HC, Bhawuk DPS et al.: Horizontal and vertical dimensions of individualism and collectivism: a theoretical and measurement refinement. Cross Cult Res 1995; 29: 240-275.

Strus W: Dojrzałość emocjonalna a funkcjonowanie moralne. Wydawnictwo Liberi Libri, Warszawa 2012.

Środa M: Indywidualizm i jego krytycy. Współczesne spory między liberałami, komunitarianami i feministkami na temat podmiotu, wspólnoty i płci. Fundacja Aletheia, Warszawa 2003.

Tamis-LeMonda CS, Way N, Hughes D et al.: Parents' goals for children: the dynamic coexistence of individualism and collectivism in cultures and individuals. Soc Dev 2007; 17: 183-209.

Tönnies F: Wspólnota i stowarzyszenie. Wydawnictwo Naukowe PWN, Warszawa 1998.

Triandis HC: Cross-cultural studies of individualism and collectivism. In: Berman JJ (ed.): Nebraska Symposium on Motivation, 1989: Cross-Cultural Perspectives. University of Nebraska Press, Lincoln 1990: 41-133.

Triandis HC: Individualism and Collectivism. Westview Press, Boulder 1995.

Triandis HC: Individualism-collectivism and personality. J Pers 2001; 69: 907-924.

Triandis HC: The self and social behavior in differing cultural contexts. Psychol Rev 1989; 96: 506-520.
Triandis HC, Gelfand MJ: Converging measurement of horizontal and vertical individualism and collectivism. J Pers Soc Psychol 1998; 74: 118-128.

Triandis HC, Bontempo R, Villareal MJ et al.: Individualism and collectivism: cross-cultural perspectives on self-ingroup relationships. J Pers Soc Psychol 1988; 54: 323-338.

Tulviste T, Mizera L: Socialization values of mothers of Estonian preadolescents. Eur J Dev Psychol 2010; 7: 295-308.

Urban M: Indywidualizm i kolektywizm w świadomości młodzieży. Studium psychologiczno-politologiczne. Dom Wydawniczy Elipsa, Warszawa 2008.

Vilar R, Liu JHF, Gouveia VV: Age and gender differences in human values: a 20-nation study. Psychol Aging 2020; 35: 345-356.

Vollebergh WAM, Iedema J, Raaijmakers QAW: Intergenerational transmission and the formation of cultural orientations in adolescence and young adulthood. J Marriage Fam 2001; 63: 1185-1198.

Vriezekolk JE, van Lankveld WGJM, Eijsbouts AMM et al.: The coping flexibility questionnaire: development and initial validation in patients with chronic rheumatic diseases. Rheumatol Int 2012; 32: 2383-2391.

Wei YS, Chu H, Chen $\mathrm{CH}$ et al.: Support groups for caregivers of intellectually disabled family members: effects on physical-psychological health and social support. J Clin Nurs 2012; 21: 1666-1677.

Witkin HA, Berry JW: Psychological differentiation in cross-cultural perspective. J Cross Cult Psychol 1975; 6: 4-87.

Yang KS: Social orientation and individual modernity among Chinese students in Taiwan. J Soc Psychol 1981; 113: 159-170.

Zimbardo PG, Gerrig RJ: Psychologia i życie. Wydawnictwo naukowe PWN, Warszawa 2006.

Zong JG, Cao XY, Cao Y et al.: Coping flexibility in college students with depressive symptoms. Health Qual Life Outcomes 2010; 8: 66. 